\title{
Harassment At Workplaces: Experiences Of Working Women
}

\author{
Mureed Hussain Laghari \\ Department of Education \\ Shaheed Benazir Bhutto University \\ Tayyaba Zarif \\ Faculty of Social Science \\ Shaheed Benazir Bhutto University \\ Safia Urooj \\ Department of Teacher Education \\ University of Karachi
}

\begin{abstract}
Harassment is a susceptible theme in socialization. It is the threatening behavior by any person or group at any place and workplace harassment is one of them. Workplace harassment is one of very sensitive areas and gaining attention by professionals and researchers. Dealing with workplace harassment is one of key indicator of effective organization. As per studies \& observations harassment happens in the workplaces but no proper record. The complete study on main theme was the thesis/research work with primary objective to study the experiences of working women regarding harassment at educational institutions from School level to University level, since the current paper is one part from the thesis work which only explores the experiences of working women at School levels consequently this research paper was to study the experiences of working women regarding harassment while working with the heads and the colleagues in public schools, consequently the study was descriptive by nature, survey method was used for data collection. The population of the study was the working women of the public schools of SBA District. Sixty five percent working women were selected as sample by the convenient random sampling for the collection of data. The Study was initiated on the basis of seven research questions which based on seven main themes related to harassment, so the items of the tool based on these themes as a result questionnaire with five points Likert was developed for data collection which was analyzed statistically. Study revealed level of experiences of women regarding verbal, physical, psychological, discriminatory, religious, cyber and immoral harassment in workplace while teaching, attending meetings, communicating with heads, colleagues and staff members. They were sometimes targeted and teased by shouting, humiliating and degrading behavior, abusive languages, frequently jokes, bullying, attacks and assaults or threats within selected Schools. It was mainly recommended that the enforcement of the law should be made sure and the heads of the institutions should provide harassment free environment for the working women.
\end{abstract}

Keywords: Harassment, Experiences, Working Women, Schools as Educational Institution, Workplaces.

This work is Licensed under a Creative Commons Attribution-NonCommercial 4.0 International License (c) () () 


\section{تلخيص}

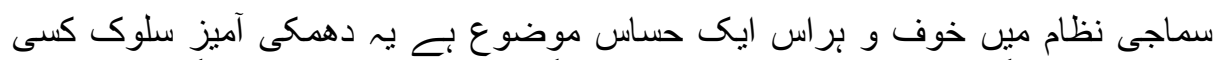

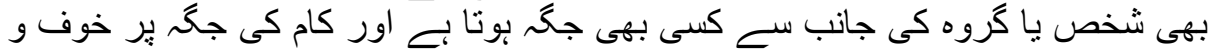

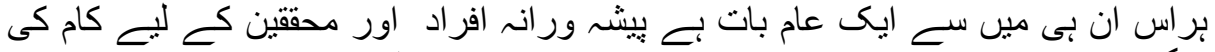

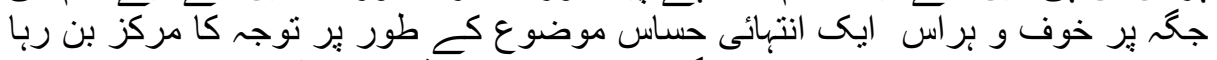

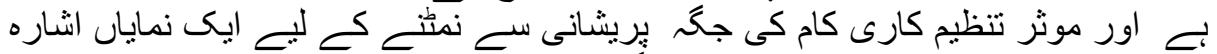

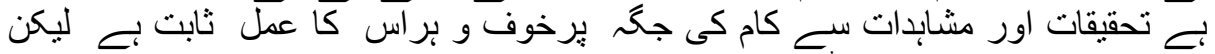

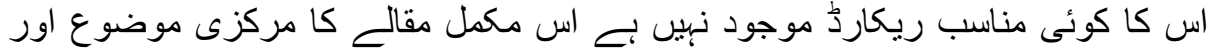

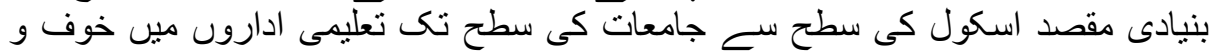

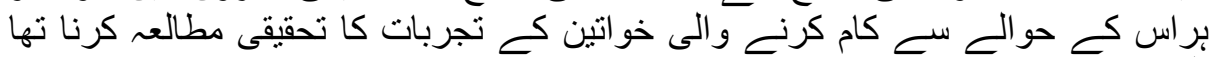

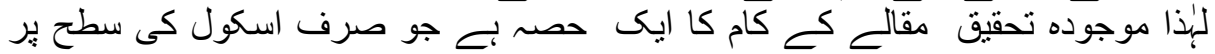

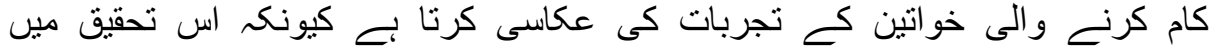

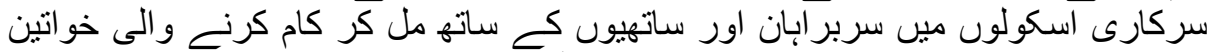

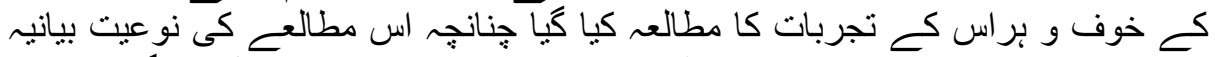

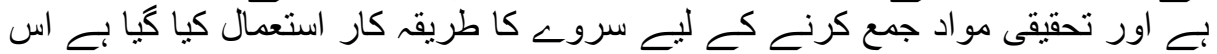

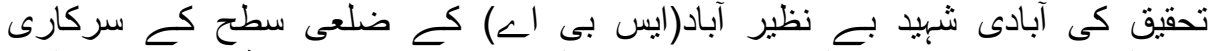

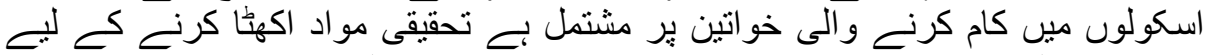

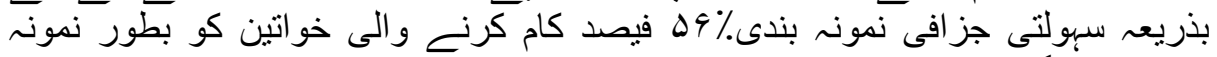

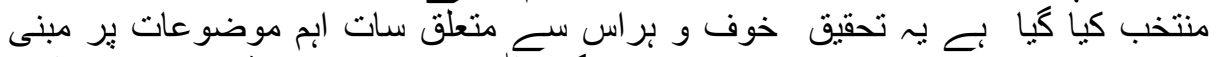

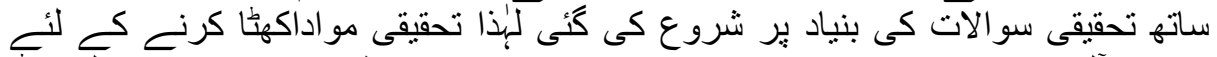

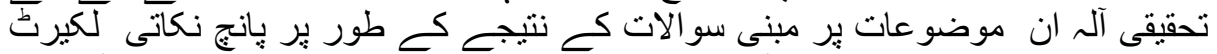

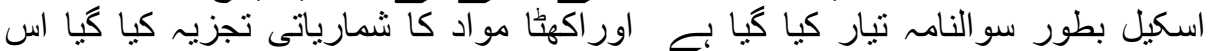

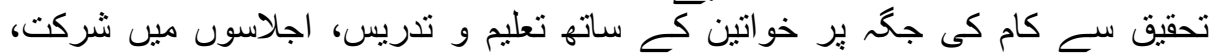

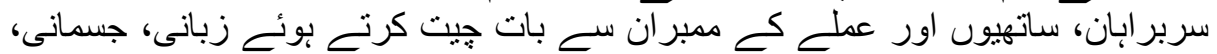

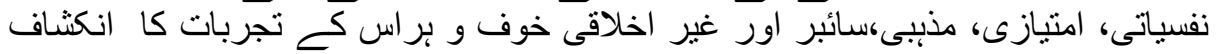

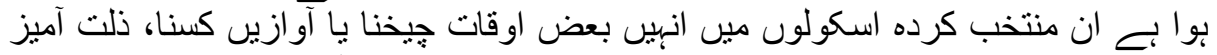

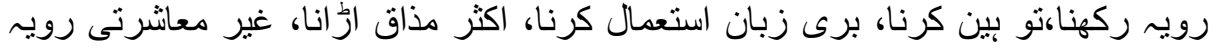

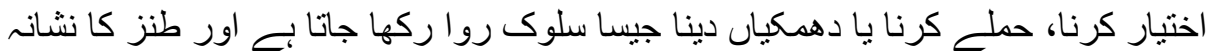

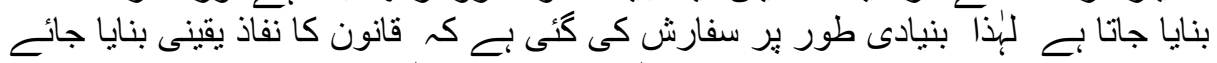

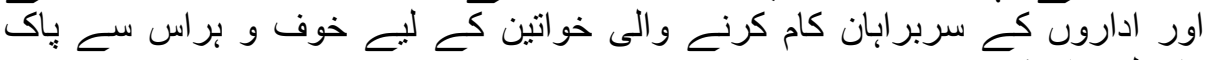
ماحول فر ابم كرين.

كليدى الفاظ: خوف و براس، تجربات،كام كرنح و الى / بِيشَ ورانه خواتين، اسكول

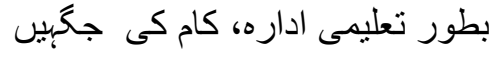

\section{Introduction}

Annoying or bothering of someone in repeated way is known as harassment (CollinsDictionary, 2019). According to Merriam-Webster Dictionary(2019) harassment is an aggressive stress or pressure. Further it includes a large range and series of behavior of 
unpleasant and offensive nature that humiliates, degrades or compels someone to do an action against the consent or to create a hostile environment. According to Agervold (2007) almost everyone without the difference of male or female, superior or subordinate may be harassed verbally, physically, discriminately or sexually. Fox \& Tang (2017) narrated that the harassment can be verbal, physical, religious, racial, cyber, age, disability, sexual and psychological. The researcher further added that the verbal harassment is occurred when the head of institute or higher authorities are unsatisfied and unhappy not because of weakness in work but personality conflict, disagreement and clash. Rigby (2007) reported that verbal harassment may include needless shouting or noise, rude or vulgar attitude, using swear words, humiliating and degrading the workers self-esteem, joking and mockery in public about ones qualifications, experience, responsibilities or work, hostile jokes or making fun of race or religion, asking dates again and again, asking about the family, tribal or racial information or hereditary problems, provoking verbally on the basis of age, ability or degrading someone on making a mistake is also included in verbal harassment. The situation of verbal harassment is made when the head of the institution is disagreeing or felling jealous with his or her competency (Blase \& Blase, 2003).

According to Gruber (2008) the physical harassment includes physical attacks, bullying, assault or threats, hitting, kicking, shoving, threatening like shaking fists angrily, destroying property to frighten, slapping or pushing someone. Discriminatory harassment may include the harassment on the basis of the race, gender, religion, disability and age of an individual (Bame, 2013). In the opinion of Law (2011) psychological harassment is very dangerous because it directly targets person's psyche and consciousness. The researcher further described that a person may be affected psychologically when harassed frequently and repeatedly and stressed by insulting, rude and abusive language, ruthless and harsh language, shoving, pulling, bullying, grabbing, giving unfeasible targets, tiny period etc that harshly affects individuals' condition of mind. It is described by Frawley (2007) that sexual harassment may include sharing sexual photos, posters, Sexual comments, jokes, questions or touching and gestures. Further it is basically provocation that is sexual in nature and by large incorporates undesirable lewd gestures, lead or conduct. Cyber harassment is the harassment by the help of the internet applications like face book, twitter, what's app Skype and emo etc (Willard, 2007). In addition to the researcher depicted that digital bullying and online harassment are a genuine worry for e people. Among many numerous different things, online harassment may include sharing mortifying things about the victim by mass email or mass visit, spread lies or babble about the victim via web-based networking media or social media and send annoying texts or instant messages specifically to the victim. Quid pro quo is Latin phrase which means "this for that". It is a kind of exchange-based sexual harassment (Davenport, 
2014). The researcher also stated that the benefits of the job are used to offer to worker on the exchange base sexual harassment. In that type of circumstances, the person who is harasser often an employer or a senior level employee may propose somewhat of worth for a sexual favor. It may also be a shape of blackmail. In the substitute for loving and romantic or sexual favor, the sufferer may get a job proposal, may get a support in promotion, may get an opportunity or stay away from a demotion or termination (McCarthy, 2014).

According to the statistics of UN regarding women about 120 million girls have experienced forced and immoral acts around the world (UN, 2015). A survey was conducted by Charity action Aid and found that a huge percentage of women who faced immoral harassment in workplace as about 57 percent in Bangladesh, 79 percent in India and 87 percent in Vietnam. Over half of the working women reported experienced of harassment and bullying by the operators of the public transportation. The situation of the working women is side hell, bullying and the harassment by the bosses at the workplace and abuse or bullying by the husband at home(True, 2012).A survey using online questionnaire as a tool was conducted in the several cities of Pakistan by TheDawn(2017) to collect the responses of the working women in the workplace in order to find whether the element of harassment is existed and found that the most of the cases of harassment were unreported and or ignored by the administration. It was also found that the elements of harassment are very common in almost all types of institutions whereas it may vary by types, nature or frequency such as verbally, physically, religiously, racially, cyber, age, disability, sexually and psychologically at workplace a working woman can be harassed by her head of the institutions, teaching staffs, non-teaching staffs or students and further reported that a very significant 35 percent working women were told and sometimes forced to remain silent by their colleagues and coworkers 59 percent reported that the subject of the harassment and bullying is treated seriously(The-Dawn, 2017). The statistics of UN regarding women harassment showed that harassment has become the global issue about 120 million girls have experienced forced and immoral acts around the world whereas it also a burning issue in Pakistan. The cases of harassment have been reported from the different cities of Pakistan. This research study deals with the experiences of working women regarding Verbal, physical, psychological, religious, racial, cyber and immoral harassment which they face while teaching, attending meetings, communicating with colleagues or staff members, and taking with the heads of the public schools during their service and to suggest the solution to prevent harassment in the public schools.

\section{Objectives of the Study}


1. To study the experiences of working women regarding Verbal harassment while working with the heads and colleagues in public schools.

2. To enquire the perception of working women regarding physical harassment while working with the Heads and colleagues in the public schools.

3. To explore the working women experiences regarding the religious and psychological Harassment during service in public schools.

4. To analyze the opinion of working women regarding cyber harassment during service in the public schools.

5. To find out the perception of working women regarding immoral harassment while working in the public schools.

6. To Understand the Knowledge level of working women regarding safeguards provided by the laws against the harassment in the workplaces.

7. To be aware the actions by head to help the victim to stop the harassment in public schools.

\section{Research Questions of the Study}

1. What are the experiences of working women regarding Verbal harassment while working with the heads and colleagues in public schools?

2. Do the working women confront the physical harassment while working with the Heads/colleagues in the public schools?

3. Do the working women deal with the religious and psychological Harassment during service in public schools?

4. What are the experiences of working women regarding cyber harassment during service in the public schools?

5. What is the perception of working women regarding immoral harassment while working in the public schools?

6. What knowledge dowork women have regarding safeguards provided by the laws against the harassment in the public schools?

7. How heads are helping the victim to stop the harassment in public schools?

\section{Review of Literature}

\section{Harassment}

Any aggressive stress or pressure, annoying or bothering of someone in repeated way is known as harassment. It is a series of behavior of unpleasant and offensive nature that humiliates, degrades or compels someone to do an action against the consent or to create an unfriendly environment. Leymann (1990) told five different forms of the actions 
which involved workplace harassment, bullying and psychological terror: (1) the reputation of the victim, (2) his or hers possibilities (3) the possibility of victims' communication with the coworkers, (4) his or her societal conditions, (5) cluster behavior of physical assault or threat. Further the inability and incapability to secure her or himself might be a straight effect and consequence of both informal or formal power and strength among the parties, the imbalanced status of the parties, are the circumlocutory and indirect consequence of the harassment, bullying and maltreatment itself. According to Einarsen, Hoel, Zapf, \& Cooper (2011) harassment and bullying usually made victim directly on the knowledgeable inadequacies on the victims' character and personality. Even if only one serious incident happened as workplace harassment and bullying gives the definitions, stressed the terminology as, "Repeated and frequent negative acts". A very close examination of the negative actions concerned has both an experimental and conceptual portion (Rayner \& Keashly, 2005).

Brodsky (1976) narrated five different forms of the harassment and bullying which are, calling with names, physical abuse, work pressure, scapegoating and sexual harassment. Direct bullying to the school children with the open verbal or physical attacks on the victim has been separated from the indirect bullying and it has been included in the efforts of separating the victim from his or her group of doing job. Asforth (1994) while studying destructive leadership described six forms of behavior of leader, superiors and managers; they are unpredictability and self-aggrandizement, criticism on subordinates, not having consideration, a forcing approach of variance resolution, discoursing scheme and non-contingent penalty or punishment. Among the 137 victims of bullying and harassment at workplace from Norwegian, isolated and excluded socially, devaluation of his or her efforts and works, disclosure to teasing or mockery and ridicule and insulting or humiliating remarks were frequently experienced unconstructive actions. However, some of the victims reported unwelcome and unpleasing sexual attention and thought to be a minor one (Leymann, 1990). Boso, L. A. (2012) told six main types of bullying and harassment at workplace are narrated in the study of 984 customers of a department of health and care units: (1) spreading gossips, rumor and slander about a person, (2) societal exclusion, (3) giving someone simple or too easy tasks, (5) a threat to fit or physical violence, (5) criticizing continuously on the other persons' work and the results, (6) mental health institutions for persons. Consequently, the difficulties of the victim in protecting himself against these attacks may be extra significant conceptual component than the real unconstructive act.

\section{South Asia is the Most Sensitive Place Regarding the Gender Issues}


According to Agarwal \& Bina (1994) narrated that South Asia is the most sensitive place regarding the gender issues. The women population of this region is higher as compare to the men. However, the women are used to discriminate on the basis of race, gender, caste, tribe, sect and the women are dependent on the men financially. Furthermore, they also deal and face with the inhuman acts especially honor killing. The provincial and state laws are unable to provide the safeguard to the women from the violence. Most of the laws are considered as apposite to women rights as Hadood laws and Qisas. Furthermore, the witness of the women is considered as half witness in court of laws. The women of our society is also not allotted due share in the different fields as per their population ratio (Agarwal \& Bina, 1994). Nevertheless, the women have proved themselves that they can perform their duties as the men can do. The women are participated in almost all fields of life whether military or civil services (Ong, 2006).

Women are working as the professor and the lecturers at the universities in the higher education and at the same time they are looking after their families at their homes. Thus, they face several challenges in the life. The sexual harassment and bullying may comprise some more requests for sexual support directly or by implication. Sometimes the promotion or academic success ordered in the exchange (Hamdan, 2005). The male students or lecturers may deliberately touch, kiss, fondle and brush to female student against her will. Very often sexually oriented comments or remarks like the comment or remarks about the physical appearance may be given or about their personal life. In addition, the display of erotic materials such as photographs, posters and pornography by visiting personally and threat of physical assault on cell phones and what's app calls or by applying any other internet application in amount to sexual harassment (Hamdan, 2005). The University of the Venda in the South Africa had a few incidents of the sexual harassment and bullying in between the year 2000 to 2004 with different female students in the different institution. A female bachelor student of Art was sexually harassed by the lecturer when she called the lecturer for some information regarding lecture classes. The lecturer touched, kissed and hugged her in his office, and it happened repeatedly. The student was very irritated and uncomfortable. This incident brought her back to the past when she was raped by her cousin (Hangartner, 2015). Spigel \& McRobbie (2007) added that the sexual harassment and bullying is a genderbased discrimination and mostly affects the female students. These types of discrimination reflect unpleasing and unwanted sexual special treatment and attention. Sexual intrusive men have a propensity to view gender relations based on the convention and script that are rather manipulative and sometimes ignored. Regarding this, male students may employ the force and power to attain their means. Thus, the rape is a sexual activity or behavior by the threat of punishment, and it includes negative performance withholding of the examination result or threat of the failing of 
students or low grades of the students. Uninvited touching, kissing, hugging or rape is sexual assaults. Cases has been reported that women are sexually assaults in their convict relationships (Spigel \& McRobbie, 2007).

\section{Condition of Harassment in Pakistan}

The immoral harassment, bullying, maltreatment, abuse and the discrimination at workplace especially in the Pakistan, are existing in the every part including the universities and schools (Gallup, 2017). A local media conducted a survey of 300 women on the harassment and harassment is not present in Pakistan but also increasing gradually (Adeel \& Yeh, 2018). A survey was conducted by Gallup in December 2017 in all Pakistan on street harassment by using online questionnaires and interviews in the various industries of Peshawar, Lahore, Islamabad and Karachi and 35 percent women were forced to remain silent by their colleagues and bosses (Gallup, 2017). Further it was found that every 1 out of 04 urban Pakistani Women have been chased or stalked by men on their way to home, office or market. This nationwide Public opinion poll about women harassment was published on $2^{\text {nd }}$ January 2018 further tells one third of the women are harassed in public transports. Every 01 out 05 women faces wolf whistling whereas every 01 out 05 women face gazes of men. 16 percent women harass by unwanted phone call (Gallup, 2017). A survey was conducted by The-Dawn (2017) and found that most of the cases were unreported and ignored by the administration. Very significant 35 percent working women were told and sometimes forced to remain silent by their colleagues and co-workers, was found in the response whether working women are made to stay silent about the workplace harassment and bullying. About 59 percent reported that the subject of the harassment and bullying is treated seriously, and others were worry about the situation which was not good. A number of legislations of protecting women including have been passed in Pakistan including Women Protection Act 2010 in Sindh Assembly whereas the law is very rarely implemented and enforced consequently the private Jirga is conducted whereas the immoral harassment is almost impossible to prove in the court of law or long duration process or from the fear of dire consequences (Khan, 2011). The researcher further narrated that Pakistani society doesn't believe that the law would provide safety. None of this is astonishing, male superiority cultural values making it almost impossible for the actions against harassers. Women protection Act 2010 provides safeguard against the workplace harassment and violence against the women it also provide safety against the domestic violence means any violence committing by the husband or by any other relatives as well as child, early or forced marriage of women and other harmful practices against the women whereas the law is also very strict on the sexual harassment and sexual violence (WPA, 2010). Article 509 of the Pakistan panel code is also given on subject to harassment and bullying against the women including sexual harassment and 
violence. In Pakistan a bill was also passed to prevent and to provide protection to the women against the domestic violence. The name of bill was Domestic Violence (Prevention and protection) Bill -2009 (The-Dawn, 2017). A policy was introduced for the development and empowerment of the women known as National policy for development and empowerment of women in 2002 for preventing domestic violence and other harmful practices against the women and girls. National Plan of action for women was introduced in 1998 in order to prevent women and girls from the domestic violence. While a number of legislations of protecting women including Women Protection Act 2010 have been passed but a very common perception among the working women is that the law is not implemented, it would not provide any safeguard to the working women regarding workplace harassment and bullying (The-Dawn, 2017). The is rarely implemented and enforced, consequently the private jirga is conducted in these types of situation around Pakistan or hide and not to share with anyone from the fear of spoiling the reputation of the family whereas the immoral sexual harassment is almost impossible to prove in the court of law or long duration process or from the fear of dire consequences. Pakistani society doesn't believe that the law would provide safety. None of this is astonishing, male superiority cultural values making it almost impossible for the actions against harassers(The-Dawn, 2017).

\section{Research Methodology}

\section{Research Design}

The design of the research study must be prepared according to the need of the research question. This study was conducted by quantitative method because the close ended questionnaire was used, and it was naturally objective and would provide numerical data regarding facts. Further this method is also used for the explanation of variable and the connection between them that helps to conclude the cause and effect among the variables whereas the quantitative research portrays some existing realities which means that it would help to collect first-hand information from the educational institutions regarding the behavior of head of the institutions and colleagues. On the status of observing and conducting report on the harassment which the working women face while teaching, meeting, talking and dealing with the heads of the institutions and colleagues during their service period in the educational institutions of SBA District.

\section{Population, Sample and Sampling}

The population of the research study was all the working women of public secondary schools of District Shaheed Benazir Abad who performing academic and administrative 
responsibilities along or under the supervision or administration of males. According to RSU (2014-15) district profile of District Shaheed Benazir Abad, there were 85 secondary schools in District Shaheed Benazir Abad, in which 404 women were working. The sample was taken 65 percent from the total population which is 262. As the population of the study was scattered in the entire district so that the convenient random sampling was selected to collect the data from the female teachers who are working in public schools of district.

\begin{tabular}{|c|c|c|c|}
\hline $\begin{array}{c}\text { Total No of } \\
\text { secondary } \\
\text { Schools }\end{array}$ & $\begin{array}{c}\text { Total number of } \\
\text { working women }\end{array}$ & Semple selected & $\begin{array}{c}\text { Total number of taken } \\
\text { samples }\end{array}$ \\
\hline 85 & 404 & $65 \%$ & 262 \\
\hline
\end{tabular}

\section{Investigative Techniques and Research Instrument}

The main theme of the research study was the experiences of working women regarding harassment in the public schools; a questionnaire was developed for the collection of data from the respondents. The Research instrument was a Likert scale of five points (1=Never, 2=Rarely, 3=Sometimes, 4=Mostly, 5=Always)which was used in the survey in order to collect the data from the respondents. The items were made to get the response from the sample in order to find the answers of all the research questions regarding verbal, physical, psychological, religious, discriminatory, cyber, immoral harassment, the knowledge regarding harassment laws and the role the head for taking actions against the complain of the harassment.

\section{Data Collection and Data Analysis Procedure}

After the endorsement of the examination of the research instrument and seeking the permission, the process of collecting data was started. The respondents were approached and assured not to leak out the responses given by the working women regarding harassment problem as understanding the sensitivity of the problem. Thenthe filled responses were collected for the analysis procedure.

\section{Data Analysis and Interpretation}

4.1 Research Question Wise Analysis

4.1.1. Analysis of Research Question No. One (Verbal harassment) 
Research question one was regarding verbal harassment for the answer of this Research Question ten items were developed, analysis is as under.

Table No: 1

Analysis of research question no one (verbal harassment)

\begin{tabular}{|l|c|c|c|c|c|}
\hline Statement No and Theme & Never & Rarely & Sometimes & Mostly & Always \\
\hline 1. Shouting needlessly by Head & $\mathrm{N}=87$ & $\mathrm{~N}=42$ & $\mathrm{~N}=92$ & $\mathrm{~N}=25$ & $\mathrm{~N}=16$ \\
& $33.2 \%$ & $16 \%$ & $35.1 \%$ & $9.54 \%$ & $6.11 \%$ \\
\hline 2. Shouting Needlessly by & $\mathrm{N}=75$ & $\mathrm{~N}=55$ & $\mathrm{~N}=91$ & $\mathrm{~N}=30$ & $\mathrm{~N}=7$ \\
colleagues & $\mathrm{S} 28.6 \%$ & $21 \%$ & $34.7 \%$ & $11.5 \%$ & $2.67 \%$ \\
\hline 3. Speaking rudely by Head & $\mathrm{N}=98$ & $\mathrm{~N}=47$ & $\mathrm{~N}=81$ & $\mathrm{~N}=26$ & $\mathrm{~N}=10$ \\
& $37.4 \%$ & $17.9 \%$ & $30.9 \%$ & $9.92 \%$ & $3.82 \%$ \\
\hline 4. Speaking rudely by colleagues & $\mathrm{N}=88$ & $\mathrm{~N}=56$ & $\mathrm{~N}=85$ & $\mathrm{~N}=26$ & $\mathrm{~N}=7$ \\
& $33.6 \%$ & $21.4 \%$ & $32.4 \%$ & $9.92 \%$ & $2.67 \%$ \\
\hline 5. Humiliating or Degrading by & $\mathrm{N}=108$ & $\mathrm{~N}=45$ & $\mathrm{~N}=79$ & $\mathrm{~N}=22$ & $\mathrm{~N}=8$ \\
head & $41.2 \%$ & $17.2 \%$ & $30.2 \%$ & $8.4 \%$ & $3.05 \%$ \\
\hline 6. Humiliating or Degrading by & $\mathrm{N}=96$ & $\mathrm{~N}=47$ & $\mathrm{~N}=90$ & $\mathrm{~N}=25$ & $\mathrm{~N}=4$ \\
colleagues & $36.6 \%$ & $17.9 \%$ & $34.4 \%$ & $9.54 \%$ & $1.53 \%$ \\
\hline 7. Making fun and joke by head & $\mathrm{N}=94$ & $\mathrm{~N}=51$ & $\mathrm{~N}=87$ & 22 & $\mathrm{~N}=8$ \\
& $35.9 \%$ & $19.5 \%$ & $33.2 \%$ & $8.4 \%$ & $3.05 \%$ \\
\hline 8. Making fun and joke by & $\mathrm{N}=93$ & $\mathrm{~N}=52$ & $\mathrm{~N}=85$ & 26 & $\mathrm{~N}=6$ \\
colleagues & $35.5 \%$ & $19.8 \%$ & $32.4 \%$ & $9.92 \%$ & $2.29 \%$ \\
\hline 9. Using abusive language by & $\mathrm{N}=113$ & $\mathrm{~N}=50$ & $\mathrm{~N}=75$ & 21 & $\mathrm{~N}=3$ \\
head & $43.1 \%$ & $19.1 \%$ & $28.6 \%$ & $8.02 \%$ & $1.15 \%$ \\
\hline 10. Using abusive language by & $\mathrm{N}=117$ & $\mathrm{~N}=51$ & $\mathrm{~N}=73$ & $\mathrm{~N}=21$ & $\mathrm{~N}=1$ \\
colleagues & $44.7 \%$ & $19.5 \%$ & $27.9 \%$ & $8.02 \%$ & $0.38 \%$ \\
\hline Verbal harassment & $\mathrm{N}=969$ & $\mathrm{~N}=496$ & $\mathrm{~N}=838$ & $\mathrm{~N}=244$ & $\mathrm{~N}=70$ \\
& $37.02 \%$ & $18.95 \%$ & $32.02 \%$ & $9.32 \%$ & $2.67 \%$ \\
\hline
\end{tabular}

Graph: 1

Analysis of research question no one (verbal harassment)

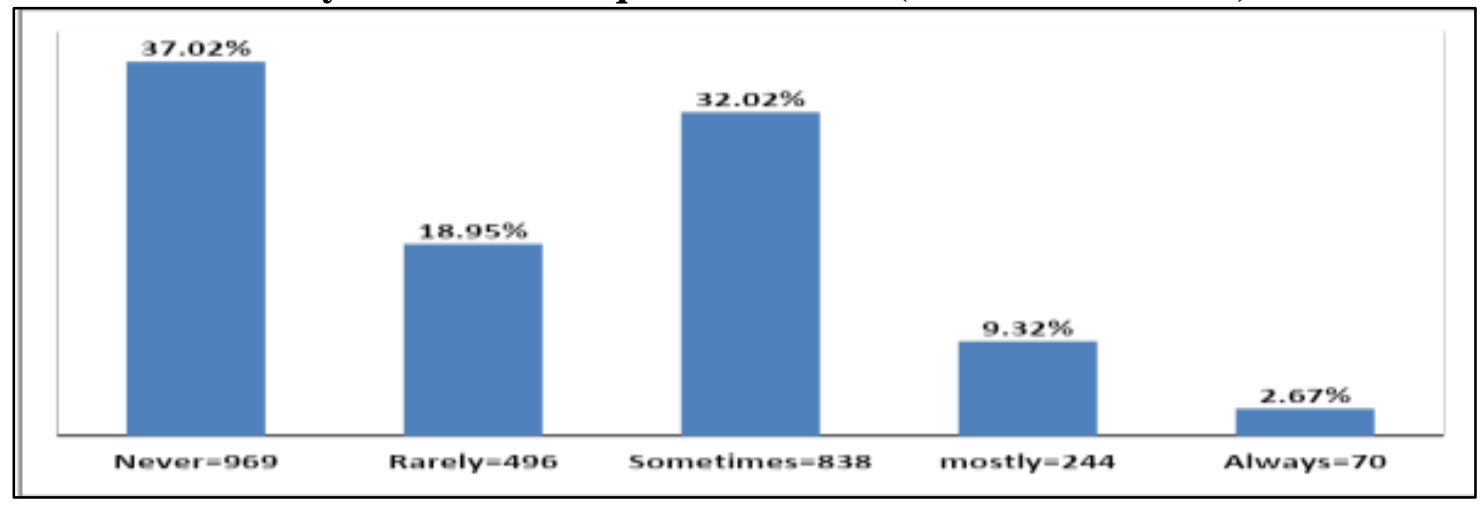


According to the above overall analysis of the items of research question number one $37.02 \%$ never, $18.95 \%$ rarely,32.02\% sometimes,9.32\% mostly,2.67\% responded always regarding experienced verbal harassment.

\section{Analysis of Research Question No. Two (Physical Harassment)}

Research question No two was regarding physical harassment for the answer of this Research Question twenty items were developed, analysis is as under.

Table: 2

Analysis of research question no two (physical harassment)

\begin{tabular}{|l|c|c|c|c|c|}
\hline Statement No and Theme & Never & Rarely & Sometimes & Mostly & Always \\
\hline 11. Attacking while talking by & $\mathrm{N}=124$ & $\mathrm{~N}=52$ & $\mathrm{~N}=62$ & $\mathrm{~N}=19$ & $\mathrm{~N}=5$ \\
head & $47.3 \%$ & $19.8 \%$ & $23.7 \%$ & $7.25 \%$ & $1.91 \%$ \\
\hline 12. Attacking while talking by & $\mathrm{N}=112$ & $\mathrm{~N}=56$ & $\mathrm{~N}=70$ & $\mathrm{~N}=17$ & $\mathrm{~N}=7$ \\
colleagues & $42.7 \%$ & $21.4 \%$ & $26.7 \%$ & $6.49 \%$ & $2.67 \%$ \\
\hline 13. Threatening while discussion & $\mathrm{N}=110$ & $\mathrm{~N}=57$ & $\mathrm{~N}=75$ & $\mathrm{~N}=18$ & $\mathrm{~N}=2$ \\
by head & $42 \%$ & $21.8 \%$ & $28.6 \%$ & $6.87 \%$ & $0.76 \%$ \\
\hline 14. Threatening while discussion & $\mathrm{N}=113$ & $\mathrm{~N}=60$ & $\mathrm{~N}=71$ & $\mathrm{~N}=15$ & $\mathrm{~N}=3$ \\
by colleagues & $43.1 \%$ & $22.9 \%$ & $27.1 \%$ & $5.73 \%$ & $1.15 \%$ \\
\hline 15. Hitting/Kicking by head & $\mathrm{N}=127$ & $\mathrm{~N}=56$ & $\mathrm{~N}=68$ & $\mathrm{~N}=10$ & $\mathrm{~N}=1$ \\
& $48.5 \%$ & $21.4 \%$ & $26 \%$ & $3.82 \%$ & $0.38 \%$ \\
\hline 16. Hitting/Kicking & $\mathrm{N}=130$ & $\mathrm{~N}=57$ & $\mathrm{~N}=63$ & $\mathrm{~N}=10$ & $\mathrm{~N}=2$ \\
colleagues & $49.6 \%$ & $21.8 \%$ & $24 \%$ & $3.82 \%$ & $0.76 \%$ \\
\hline 17. Shaking fists angrily by head & $\mathrm{N}=128$ & $\mathrm{~N}=54$ & $\mathrm{~N}=67$ & $\mathrm{~N}=10$ & $\mathrm{~N}=3$ \\
& $48.9 \%$ & $20.6 \%$ & $25.6 \%$ & $3.82 \%$ & $1.15 \%$ \\
\hline 18. Shaking fists angrily by & $\mathrm{N}=124$ & $\mathrm{~N}=59$ & $\mathrm{~N}=67$ & $\mathrm{~N}=9$ & $\mathrm{~N}=3$ \\
colleagues & $47.3 \%$ & $22.5 \%$ & $25.6 \%$ & $3.44 \%$ & $1.15 \%$ \\
\hline 19. Frightening by head & $\mathrm{N}=128$ & $\mathrm{~N}=54$ & $\mathrm{~N}=68$ & $\mathrm{~N}=9$ & $\mathrm{~N}=3$ \\
& $48.9 \%$ & $20.6 \%$ & $26 \%$ & $3.44 \%$ & $1.15 \%$ \\
\hline 20. Frightening by colleagues & $\mathrm{N}=133$ & $\mathrm{~N}=49$ & $\mathrm{~N}=69$ & $\mathrm{~N}=7$ & $\mathrm{~N}=4$ \\
& $50.8 \%$ & $18.7 \%$ & $26.3 \%$ & $2.67 \%$ & $1.53 \%$ \\
\hline 21. Holding hands/Body by head & $\mathrm{N}=135$ & $\mathrm{~N}=50$ & $\mathrm{~N}=66$ & $\mathrm{~N}=8$ & $\mathrm{~N}=3$ \\
& $51.5 \%$ & $19.1 \%$ & $25.2 \%$ & $3.05 \%$ & $1.15 \%$ \\
\hline 22.Holding hands/body by & $\mathrm{N}=133$ & $\mathrm{~N}=50$ & $\mathrm{~N}=66$ & $\mathrm{~N}=12$ & $\mathrm{~N}=1$ \\
colleagues & $50.8 \%$ & $19.1 \%$ & $25.2 \%$ & $4.58 \%$ & $0.38 \%$ \\
\hline 23. Throwing objects to frighten & $\mathrm{N}=130$ & $\mathrm{~N}=52$ & $\mathrm{~N}=64$ & $\mathrm{~N}=14$ & $\mathrm{~N}=2$ \\
by head & $49.6 \%$ & $19.8 \%$ & $24.4 \%$ & $5.34 \%$ & $0.76 \%$ \\
\hline 24.Throwing objects to frighten & $\mathrm{N}=129$ & $\mathrm{~N}=51$ & $\mathrm{~N}=70$ & $\mathrm{~N}=10$ & $\mathrm{~N}=2$ \\
by colleagues & $49.2 \%$ & $19.5 \%$ & $26.7 \%$ & $3.82 \%$ & $0.76 \%$ \\
\hline 25. Assaulting by head & $\mathrm{N}=127$ & $\mathrm{~N}=57$ & $\mathrm{~N}=63$ & $\mathrm{~N}=12$ & $\mathrm{~N}=3$ \\
& $48.5 \%$ & $21.8 \%$ & $24 \%$ & $4.58 \%$ & $1.15 \%$ \\
\hline 26. Assaulting by colleagues & $\mathrm{N}=128$ & $\mathrm{~N}=58$ & $\mathrm{~N}=63$ & $\mathrm{~N}=11$ & $\mathrm{~N}=2$ \\
& $48.9 \%$ & $22.1 \%$ & $24 \%$ & $4.2 \%$ & $0.76 \%$ \\
\hline 27. Shoving by head & $\mathrm{N}=134$ & $\mathrm{~N}=55$ & $\mathrm{~N}=61$ & $\mathrm{~N}=11$ & $\mathrm{~N}=1$ \\
\hline
\end{tabular}




\begin{tabular}{|l|c|c|c|c|c|}
\hline & $51.1 \%$ & $21 \%$ & $23.3 \%$ & $4.2 \%$ & $0.38 \%$ \\
\hline 28. Shoving by colleagues & $\mathrm{N}=134$ & $\mathrm{~N}=49$ & $\mathrm{~N}=68$ & $\mathrm{~N}=9$ & $\mathrm{~N}=2$ \\
& $51.1 \%$ & $18.7 \%$ & $26 \%$ & $3.44 \%$ & $0.76 \%$ \\
\hline 29.Hitting himself to frighten by & $\mathrm{N}=136$ & $\mathrm{~N}=49$ & $\mathrm{~N}=65$ & $\mathrm{~N}=10$ & $\mathrm{~N}=2$ \\
head & $51.9 \%$ & $18.7 \%$ & $24.8 \%$ & $3.82 \%$ & $0.76 \%$ \\
\hline 30.Hitting himself to frighten by & $\mathrm{N}=137$ & $\mathrm{~N}=50$ & $\mathrm{~N}=68$ & $\mathrm{~N}=6$ & $\mathrm{~N}=1$ \\
colleagues & $52.3 \%$ & $19.1 \%$ & $26 \%$ & $2.29 \%$ & $0.38 \%$ \\
\hline Physical Harassment & $\mathrm{N}=2552$ & $\mathrm{~N}=1075$ & $\mathrm{~N}=1334$ & $\mathrm{~N}=227$ & $\mathrm{~N}=52$ \\
& $48.70 \%$ & $20.51 \%$ & $25.45 \%$ & $4.33 \%$ & $0.99 \%$ \\
\hline
\end{tabular}

Graph: 2

Analysis of Research Question No Two (Physical Harassment)

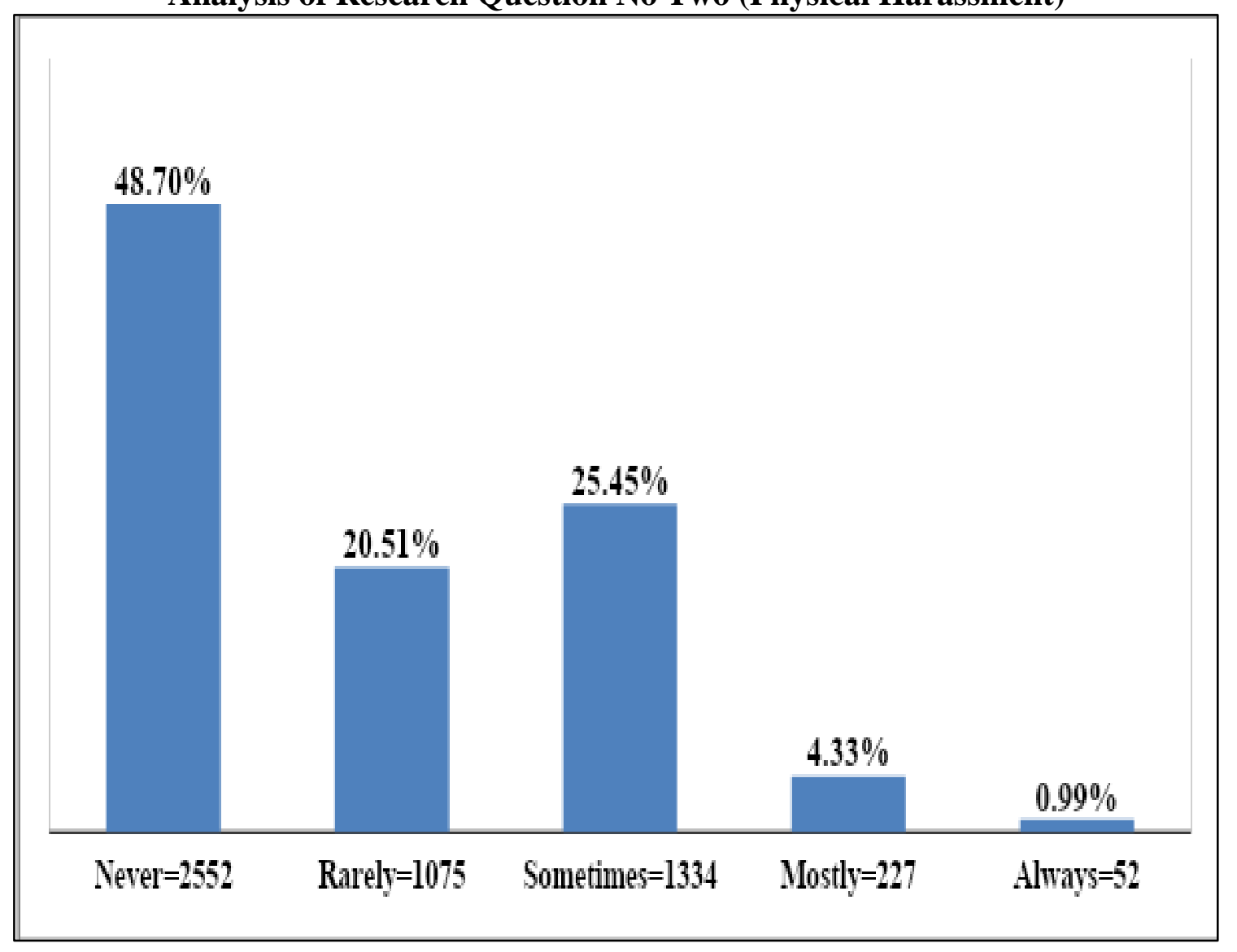

According to the above overall $48.70 \%$ never, $20.51 \%$ rarely, $25.45 \%$ sometimes, $4.33 \%$ mostly, $0.99 \%$ responded always regarding experienced physical harassment.

Analysis of Research Question No Three (Religious and Psychological Harassment) 
Research question No three was regarding religious and psychological harassment for the answer of this Research Question fourteen items were developed, analysis is as under.

Table: 3

Analysis of research question no three (religious and psychological harassment)

\begin{tabular}{|l|c|c|c|c|c|}
\hline StatementNo and Theme & Never & Rarely & $\begin{array}{c}\text { Some } \\
\text { times }\end{array}$ & Mostly & Always \\
\hline 31.Targeting based on race by head & $\begin{array}{c}\mathrm{N}=131 \\
50 \%\end{array}$ & $\begin{array}{c}\mathrm{N}=49 \\
18.7 \%\end{array}$ & $\begin{array}{c}\mathrm{N}=66 \\
25.2 \%\end{array}$ & $\begin{array}{c}\mathrm{N}=9 \\
3.44 \%\end{array}$ & $\mathrm{~N}=7$ \\
& $\mathrm{~N}=125$ & $\mathrm{~N}=50$ & $\mathrm{~N}=71$ & $\mathrm{~N}=12$ & $\mathrm{~N}=4$ \\
\hline 32.Targeting based on race by & $47.7 \%$ & $19.1 \%$ & $27.1 \%$ & $4.58 \%$ & $1.53 \%$ \\
colleagues & $\mathrm{N}=133$ & $\mathrm{~N}=48$ & $\mathrm{~N}=68$ & $\mathrm{~N}=9$ & $\mathrm{~N}=4$ \\
\hline 33. Targeting based on gender by \\
head & $50.8 \%$ & $18.3 \%$ & $26 \%$ & $3.44 \%$ & $1.53 \%$ \\
\hline 34.Targeting based on gender by & $\mathrm{N}=132$ & $\mathrm{~N}=57$ & $\mathrm{~N}=65$ & $\mathrm{~N}=5$ & $\mathrm{~N}=3$ \\
colleagues & $50.4 \%$ & $21.8 \%$ & $24.8 \%$ & $1.91 \%$ & $1.15 \%$ \\
\hline 35. Targeting based on religion by & $\mathrm{N}=135$ & $\mathrm{~N}=58$ & $\mathrm{~N}=54$ & $\mathrm{~N}=9$ & $\mathrm{~N}=6$ \\
head & $51.5 \%$ & $22.1 \%$ & $20.6 \%$ & $3.44 \%$ & $2.29 \%$ \\
\hline 36.Targeting based on religion by & $\mathrm{N}=135$ & $\mathrm{~N}=54$ & $\mathrm{~N}=60$ & $\mathrm{~N}=10$ & $\mathrm{~N}=3$ \\
colleagues & $51.5 \%$ & $20.6 \%$ & $22.9 \%$ & $3.82 \%$ & $1.15 \%$ \\
\hline 37. Targeting based on disability by & $\mathrm{N}=147$ & $\mathrm{~N}=49$ & $\mathrm{~N}=59$ & $\mathrm{~N}=6$ & $\mathrm{~N}=1$ \\
head & $56.1 \%$ & $18.7 \%$ & $22.5 \%$ & $2.29 \%$ & $0.38 \%$ \\
\hline 38. Targeting based on disability by & $\mathrm{N}=144$ & $\mathrm{~N}=49$ & $\mathrm{~N}=63$ & $\mathrm{~N}=4$ & $\mathrm{~N}=2$ \\
colleagues & $55 \%$ & $18.7 \%$ & $24 \%$ & $1.53 \%$ & $0.76 \%$ \\
\hline 39. Targeting based on age by head & $\mathrm{N}=141$ & $\mathrm{~N}=52$ & $\mathrm{~N}=63$ & $\mathrm{~N}=5$ & $\mathrm{~N}=1$ \\
& $53.8 \%$ & $19.8 \%$ & $24 \%$ & $1.91 \%$ & $0.38 \%$ \\
\hline 40. Targeting based on age by & $\mathrm{N}=128$ & $\mathrm{~N}=55$ & $\mathrm{~N}=66$ & $\mathrm{~N}=8$ & $\mathrm{~N}=4$ \\
colleagues & $48.9 \%$ & $21 \%$ & $25.2 \%$ & $3.05 \%$ & $1.53 \%$ \\
\hline 41. Using harsh language by head & $\mathrm{N}=143$ & $\mathrm{~N}=67$ & $\mathrm{~N}=39$ & $\mathrm{~N}=7$ & $\mathrm{~N}=6$ \\
& $54.6 \%$ & $25.6 \%$ & $14.9 \%$ & $2.67 \%$ & $2.29 \%$ \\
\hline 42.Using harsh language by & $\mathrm{N}=133$ & $\mathrm{~N}=83$ & $\mathrm{~N}=40$ & $\mathrm{~N}=5$ & $\mathrm{~N}=1$ \\
colleagues & $50.8 \%$ & $31.7 \%$ & $15.3 \%$ & $1.91 \%$ & $0.38 \%$ \\
\hline 43. Grabbing continuously by head & $\mathrm{N}=160$ & $\mathrm{~N}=69$ & $\mathrm{~N}=28$ & $\mathrm{~N}=5$ & $\mathrm{~N}=0$ \\
& $61.1 \%$ & $26.3 \%$ & $10.7 \%$ & $1.91 \%$ & $0 \%$ \\
\hline 44.Grabbing continuously by & $\mathrm{N}=159$ & $\mathrm{~N}=65$ & $\mathrm{~N}=34$ & $\mathrm{~N}=4$ & $\mathrm{~N}=0$ \\
colleagues & $60.7 \%$ & $24.8 \%$ & $13 \%$ & $1.53 \%$ & $0 \%$ \\
\hline Religious and Psychological & $\mathrm{N}=2106$ & $\mathrm{~N}=805$ & $\mathrm{~N}=776$ & $\mathrm{~N}=98$ & $\mathrm{~N}=42$ \\
harassment & $53.06 \%$ & $21.95 \%$ & $20.66 \%$ & $2.67 \%$ & $1.14 \%$ \\
\hline
\end{tabular}




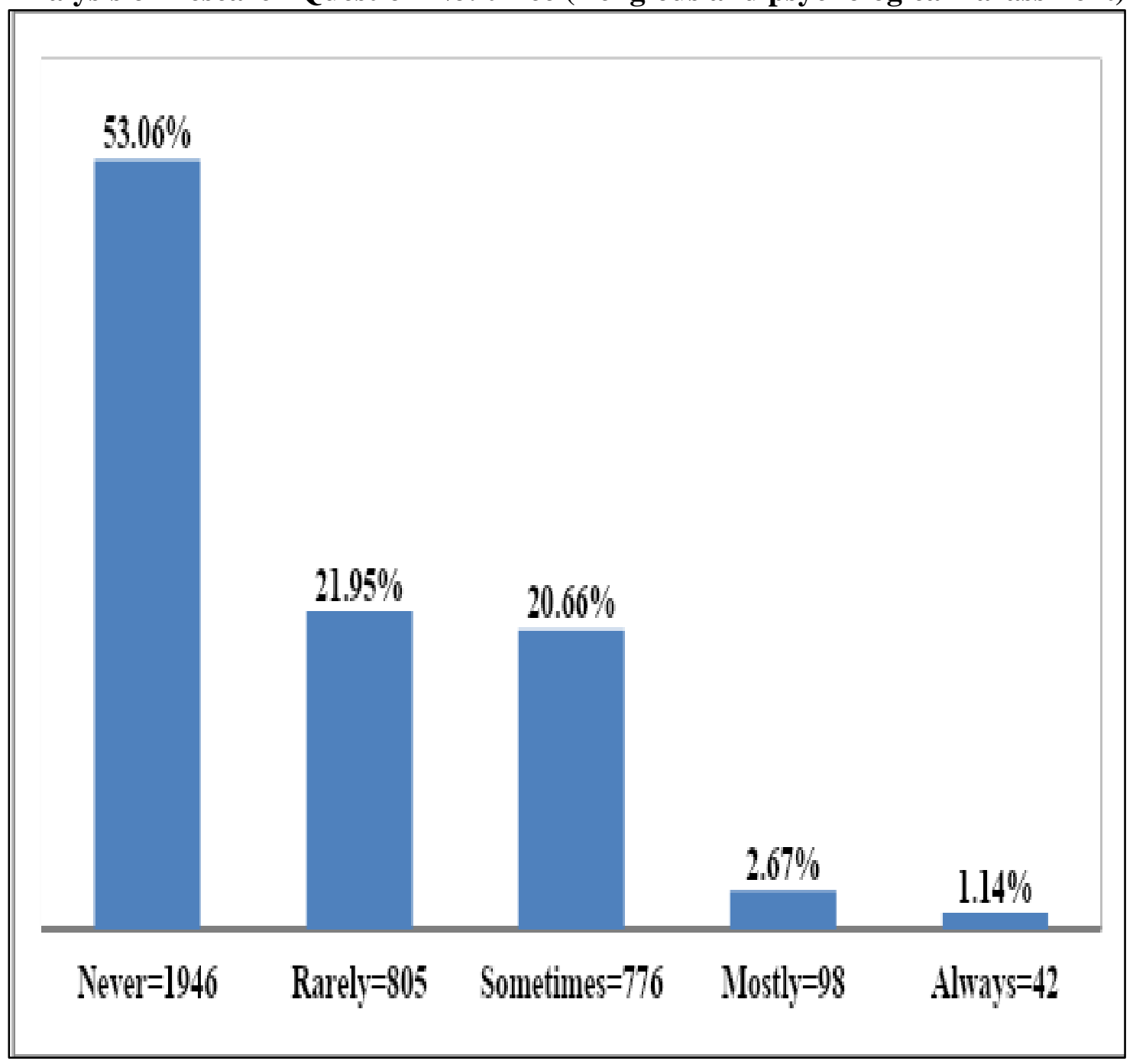

According to the above overall analysis $53.06 \%$ responded never, $21.95 \%$ responded rarely, $20.66 \%$ responded sometimes, $2.67 \%$ responded mostly, $1.14 \%$ responded always regarding experienced religious and psychological harassment.

\section{Analysis of Research Question No Four (Cyber Harassment)}


Research question No four was regarding cyber harassment for the answer of this Research Question fourteen items were developed, analysis is as under.

Table: 4

Analysis of research question no four (cyber harassment)

\begin{tabular}{|c|c|c|c|c|c|}
\hline StatementNo and Theme & Never & Rarely & $\begin{array}{l}\text { Some } \\
\text { times }\end{array}$ & Mostly & Always \\
\hline 45.Head spreading lie by internet & $\begin{array}{l}N=160 \\
61.1 \%\end{array}$ & $\begin{array}{l}\mathrm{N}=59 \\
22.5 \%\end{array}$ & $\begin{array}{l}\mathrm{N}=36 \\
13.7 \%\end{array}$ & $\begin{array}{l}\mathrm{N}=6 \\
2.29 \%\end{array}$ & $\begin{array}{l}\mathrm{N}=1 \\
0.38 \% \\
\end{array}$ \\
\hline 46.Colleagues spreading lie by internet & $\begin{array}{l}\mathrm{N}=158 \\
60.3 \%\end{array}$ & $\begin{array}{l}\mathrm{N}=63 \\
24 \%\end{array}$ & $\begin{array}{l}\mathrm{N}=34 \\
13 \%\end{array}$ & $\begin{array}{l}\mathrm{N}=6 \\
2.29 \%\end{array}$ & $\begin{array}{l}\mathrm{N}=1 \\
0.38 \%\end{array}$ \\
\hline 47.Head sending texts by internet & $\begin{array}{l}\mathrm{N}=125 \\
47.7 \%\end{array}$ & $\begin{array}{l}\mathrm{N}=64 \\
24.4 \%\end{array}$ & $\begin{array}{l}\mathrm{N}=37 \\
14.1 \%\end{array}$ & $\begin{array}{l}\mathrm{N}=11 \\
4.2 \%\end{array}$ & $\begin{array}{l}\mathrm{N}=25 \\
9.54 \%\end{array}$ \\
\hline 48.Colleagues sending text by internet & $\begin{array}{l}\mathrm{N}=117 \\
44.7 \%\end{array}$ & $\begin{array}{l}\mathrm{N}=69 \\
26.3 \%\end{array}$ & $\begin{array}{l}\mathrm{N}=43 \\
16.4 \%\end{array}$ & $\begin{array}{l}\mathrm{N}=11 \\
4.2 \%\end{array}$ & $\begin{array}{l}\mathrm{N}=22 \\
8.4 \%\end{array}$ \\
\hline $\begin{array}{l}\text { 49.Head sending unwanted material by } \\
\text { internet }\end{array}$ & $\begin{array}{l}\mathrm{N}=165 \\
63 \%\end{array}$ & $\begin{array}{l}\mathrm{N}=57 \\
21.8 \%\end{array}$ & $\begin{array}{l}\mathrm{N}=32 \\
12.2 \%\end{array}$ & $\begin{array}{l}\mathrm{N}=7 \\
2.67 \%\end{array}$ & $\begin{array}{l}\mathrm{N}=1 \\
0.38 \% \\
\end{array}$ \\
\hline $\begin{array}{l}\text { 50.Colleagues sending unwanted } \\
\text { material by internet }\end{array}$ & $\begin{array}{l}\mathrm{N}=162 \\
61.8 \%\end{array}$ & $\begin{array}{l}\mathrm{N}=62 \\
23.7 \%\end{array}$ & $\begin{array}{l}\mathrm{N}=32 \\
12.2 \%\end{array}$ & $\begin{array}{l}\mathrm{N}=4 \\
1.53 \%\end{array}$ & $\begin{array}{l}\mathrm{N}=2 \\
0.76 \%\end{array}$ \\
\hline 51.Head calling by internet & $\begin{array}{l}\mathrm{N}=153 \\
58.4 \%\end{array}$ & $\begin{array}{l}\mathrm{N}=67 \\
25.6 \%\end{array}$ & $\begin{array}{l}\mathrm{N}=28 \\
10.7 \%\end{array}$ & $\begin{array}{l}\mathrm{N}=9 \\
3.44 \%\end{array}$ & $\begin{array}{l}\mathrm{N}=5 \\
1.91 \% \\
\end{array}$ \\
\hline 52.Colleagues calling by internet & $\begin{array}{l}\mathrm{N}=144 \\
55 \%\end{array}$ & $\begin{array}{l}\mathrm{N}=68 \\
26 \%\end{array}$ & $\begin{array}{l}\mathrm{N}=39 \\
14.9 \% \\
\end{array}$ & $\begin{array}{l}\mathrm{N}=4 \\
1.53 \%\end{array}$ & $\begin{array}{l}\mathrm{N}=7 \\
2.67 \% \\
\end{array}$ \\
\hline 53.Head giving annoying comments & $\begin{array}{l}\mathrm{N}=171 \\
65.3 \%\end{array}$ & $\begin{array}{l}\mathrm{N}=58 \\
22.1 \% \\
\end{array}$ & $\begin{array}{l}\mathrm{N}=27 \\
10.3 \% \\
\end{array}$ & $\begin{array}{l}\mathrm{N}=5 \\
1.91 \%\end{array}$ & $\begin{array}{l}\mathrm{N}=1 \\
0.38 \% \\
\end{array}$ \\
\hline $\begin{array}{l}\text { 54.Colleagues giving annoying } \\
\text { comments }\end{array}$ & $\begin{array}{l}\mathrm{N}=165 \\
63 \%\end{array}$ & $\begin{array}{l}\mathrm{N}=55 \\
21 \%\end{array}$ & $\begin{array}{l}\mathrm{N}=34 \\
13 \%\end{array}$ & $\begin{array}{l}\mathrm{N}=4 \\
1.53 \%\end{array}$ & $\begin{array}{l}\mathrm{N}=4 \\
1.53 \% \\
\end{array}$ \\
\hline 55.Head sharing humiliating things & $\begin{array}{l}\mathrm{N}=170 \\
64.9 \%\end{array}$ & $\begin{array}{l}\mathrm{N}=59 \\
22.5 \%\end{array}$ & $\begin{array}{l}\mathrm{N}=29 \\
11.1 \% \\
\end{array}$ & $\begin{array}{l}\mathrm{N}=2 \\
0.76 \%\end{array}$ & $\begin{array}{l}\mathrm{N}=2 \\
0.76 \% \\
\end{array}$ \\
\hline $\begin{array}{l}\text { 56.Colleagues sharing humiliating } \\
\text { things }\end{array}$ & $\begin{array}{l}\mathrm{N}=169 \\
64.5 \%\end{array}$ & $\begin{array}{l}\mathrm{N}=61 \\
23.3 \%\end{array}$ & $\begin{array}{l}\mathrm{N}=25 \\
9.54 \%\end{array}$ & $\begin{array}{l}\mathrm{N}=5 \\
1.91 \%\end{array}$ & $\begin{array}{l}\mathrm{N}=2 \\
0.76 \% \\
\end{array}$ \\
\hline 57.Head sharing immoral material & $\begin{array}{l}N=177 \\
67.6 \%\end{array}$ & $\begin{array}{l}\mathrm{N}=59 \\
22.5 \%\end{array}$ & $\begin{array}{l}\mathrm{N}=22 \\
8.4 \%\end{array}$ & $\begin{array}{l}\mathrm{N}=3 \\
1.15 \%\end{array}$ & $\begin{array}{l}\mathrm{N}=1 \\
0.38 \%\end{array}$ \\
\hline 58.Colleagues sharing immoral material & $\begin{array}{l}N=176 \\
67.2 \%\end{array}$ & $\begin{array}{l}\mathrm{N}=55 \\
21 \%\end{array}$ & $\begin{array}{l}\mathrm{N}=26 \\
9.92 \%\end{array}$ & $\begin{array}{l}\mathrm{N}=3 \\
1.15 \%\end{array}$ & $\begin{array}{l}\mathrm{N}=2 \\
0.76 \%\end{array}$ \\
\hline Cyber Harassment & $\begin{array}{l}N=1946 \\
60.30 \%\end{array}$ & $\begin{array}{l}N=856 \\
23.33 \%\end{array}$ & $\begin{array}{l}\mathrm{N}=444 \\
12.10 \%\end{array}$ & $\begin{array}{l}\mathrm{N}=80 \\
2.18 \%\end{array}$ & $\begin{array}{l}\mathrm{N}=76 \\
2.07 \%\end{array}$ \\
\hline
\end{tabular}

Graph: 4 Analysis of research question no four (cyber harassment) 


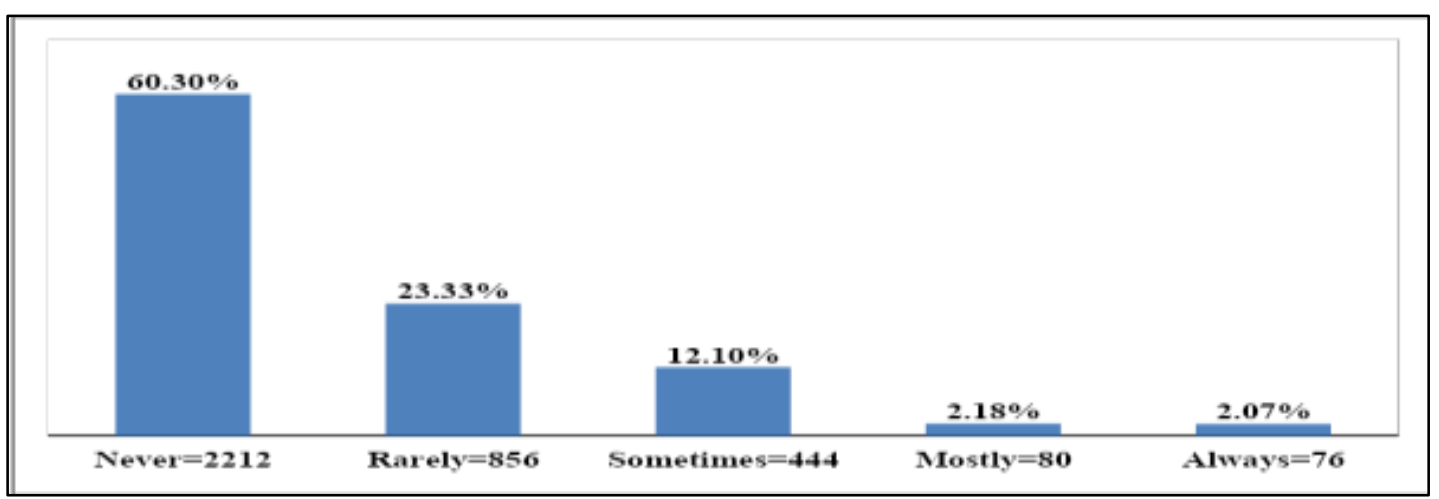

According to the above overall analysis $60.30 \%$ responded never, $23.33 \%$ responded rarely, $12.10 \%$ responded sometimes, $2.18 \%$ responded mostly, $2.07 \%$ responded always regarding experienced cyber harassment.

\section{Analysis of Research Question No Five (Immoral Harassment)}

Research question No five was the experiences of working women regarding immoral harassment for the answer of this Research Question eight items were developed, analysis is as under.

Table: 5

Analysis of research question no five (immoral harassment)

\begin{tabular}{|c|c|c|c|c|c|}
\hline Statement No \& Theme & Never & Rarely & $\begin{array}{l}\text { Some } \\
\text { times }\end{array}$ & Mostly & Always \\
\hline $\begin{array}{l}\text { 59.Head sharing immoral material } \\
\text { personally }\end{array}$ & $\begin{array}{l}\mathrm{N}=173 \\
66 \%\end{array}$ & $\begin{array}{l}\mathrm{N}=54 \\
20.6 \%\end{array}$ & $\begin{array}{l}\mathrm{N}=32 \\
12.2 \%\end{array}$ & $\begin{array}{l}\mathrm{N}=2 \\
0.76 \%\end{array}$ & $\begin{array}{l}\mathrm{N}=1 \\
0.38 \%\end{array}$ \\
\hline $\begin{array}{l}\text { 60.Colleagues sharing immoral material } \\
\text { personally }\end{array}$ & $\begin{array}{l}\mathrm{N}=170 \\
64.9 \%\end{array}$ & $\begin{array}{l}\mathrm{N}=53 \\
20.2 \%\end{array}$ & $\begin{array}{l}\mathrm{N}=35 \\
13.4 \%\end{array}$ & $\begin{array}{l}\mathrm{N}=4 \\
1.53 \%\end{array}$ & $\begin{array}{l}\mathrm{N}=0 \\
0 \%\end{array}$ \\
\hline 61.Head giving immoral comments & $\begin{array}{l}\mathrm{N}=162 \\
61.8 \%\end{array}$ & $\begin{array}{l}\mathrm{N}=57 \\
21.8 \%\end{array}$ & $\begin{array}{l}\mathrm{N}=34 \\
13 \%\end{array}$ & $\begin{array}{l}\mathrm{N}=8 \\
3.05 \%\end{array}$ & $\begin{array}{l}\mathrm{N}=1 \\
0.38 \%\end{array}$ \\
\hline $\begin{array}{l}\text { 62. Colleagues giving immoral } \\
\text { comments }\end{array}$ & $\begin{array}{l}\mathrm{N}=158 \\
60.3 \%\end{array}$ & $\begin{array}{l}\mathrm{N}=57 \\
21.8 \%\end{array}$ & $\begin{array}{l}\mathrm{N}=39 \\
14.9 \%\end{array}$ & $\begin{array}{l}\mathrm{N}=8 \\
3.05 \%\end{array}$ & $\begin{array}{l}\mathrm{N}=0 \\
0 \%\end{array}$ \\
\hline 63.Head asking immoral questions & $\begin{array}{l}\mathrm{N}=160 \\
61.1 \%\end{array}$ & $\begin{array}{l}\mathrm{N}=59 \\
22.5 \%\end{array}$ & $\begin{array}{l}\mathrm{N}=33 \\
12.6 \%\end{array}$ & $\begin{array}{l}\mathrm{N}=8 \\
3.05 \%\end{array}$ & $\begin{array}{l}\mathrm{N}=2 \\
0.76 \%\end{array}$ \\
\hline 64.Colleague asking immoral questions & $\begin{array}{l}\mathrm{N}=158 \\
60.3 \%\end{array}$ & $\begin{array}{l}\mathrm{N}=57 \\
21.8 \%\end{array}$ & $\begin{array}{l}\mathrm{N}=38 \\
14.5 \%\end{array}$ & $\begin{array}{l}\mathrm{N}=6 \\
2.29 \%\end{array}$ & $\begin{array}{l}\mathrm{N}=3 \\
1.15 \%\end{array}$ \\
\hline 65.Head proposing for immoral favor & $\begin{array}{l}\mathrm{N}=166 \\
63.4 \%\end{array}$ & $\begin{array}{l}\mathrm{N}=51 \\
19.5 \%\end{array}$ & $\begin{array}{l}\mathrm{N}=36 \\
13.7 \%\end{array}$ & $\begin{array}{l}\mathrm{N}=6 \\
2.29 \%\end{array}$ & $\begin{array}{l}\mathrm{N}=3 \\
1.15 \%\end{array}$ \\
\hline $\begin{array}{l}\text { 66.Colleagues proposing for immoral } \\
\text { favor }\end{array}$ & $\begin{array}{l}\mathrm{N}=158 \\
60.3 \%\end{array}$ & $\begin{array}{l}\mathrm{N}=56 \\
21.4 \%\end{array}$ & $\begin{array}{l}\mathrm{N}=35 \\
13.4 \%\end{array}$ & $\begin{array}{l}\mathrm{N}=12 \\
4.58 \%\end{array}$ & $\begin{array}{l}\mathrm{N}=1 \\
0.38 \%\end{array}$ \\
\hline Immoral harassment & $\begin{array}{l}\mathrm{N}=1305 \\
68.82 \%\end{array}$ & $\begin{array}{l}\mathrm{N}=444 \\
23.41 \%\end{array}$ & $\begin{array}{l}\mathrm{N}=282 \\
14.87 \%\end{array}$ & $\begin{array}{l}\mathrm{N}=54 \\
2.84 \%\end{array}$ & $\begin{array}{l}\mathrm{N}=11 \\
0.58 \%\end{array}$ \\
\hline
\end{tabular}

\section{Graph:5}

\section{Analysis of research question no five (immoral harassment)}




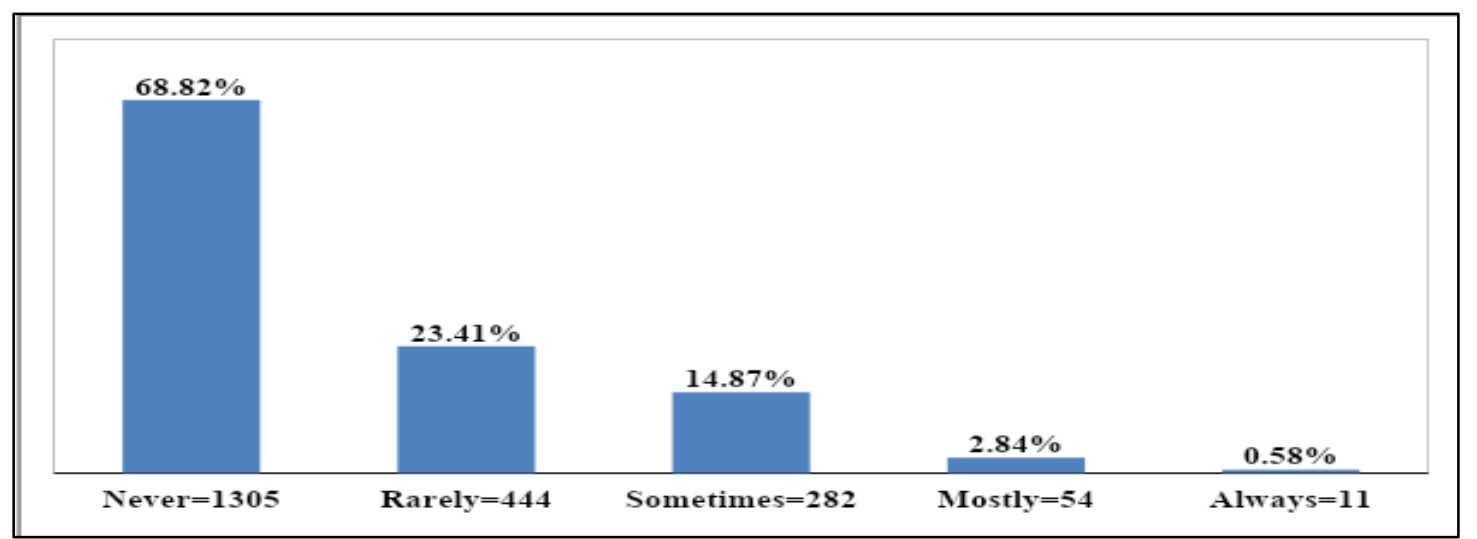

According to the above overall analysis of the items of research question number five revealed that $68.82 \%$ responded never, $23.41 \%$ responded rarely, $14.87 \%$ responded sometimes, $2.84 \%$ respondedmostly, $0.58 \%$ responded always regarding experienced immoral harassment.

\section{Analysis of Research Question No. Six (Knowledge of Harassment Laws)}

Research question No six was regarding the safeguards provided by the laws against the workplace harassment for the answer of this Research Question four items were developed, analysis is as under.

Table:6

Analysis of research question no six (knowledge of harassment laws)

\begin{tabular}{|l|l|l|l|l|l|}
\hline Statement No \& Theme & Never & Rarely & $\begin{array}{l}\text { Some } \\
\text { times }\end{array}$ & Mostly & Always \\
\hline $\begin{array}{l}\text { 67. Orientation session regarding } \\
\text { knowledge of harassment laws }\end{array}$ & $\begin{array}{l}\mathrm{N}=116 \\
44.3 \%\end{array}$ & $\begin{array}{l}\mathrm{N}=54 \\
20.6 \%\end{array}$ & $\begin{array}{l}\mathrm{N}=51 \\
19.5 \%\end{array}$ & $\begin{array}{l}\mathrm{N}=19 \\
7.25 \%\end{array}$ & $\mathrm{~N}=22$ \\
\hline 68. laws providing the safeguards & $\mathrm{N}=71$ & $\mathrm{~N}=21$ & $\mathrm{~N}=84$ & $\mathrm{~N}=55$ & $\mathrm{~N}=31$ \\
& $27.1 \%$ & $8.02 \%$ & $32.1 \%$ & $21 \%$ & $11.8 \%$ \\
\hline 69. Taking help from the laws & $\mathrm{N}=97$ & $\mathrm{~N}=19$ & $\mathrm{~N}=73$ & $\mathrm{~N}=51$ & $\mathrm{~N}=22$ \\
& $37 \%$ & $7.25 \%$ & $27.9 \%$ & $19.5 \%$ & $8.4 \%$ \\
\hline 70. Colleagues taking help from & $\mathrm{N}=94$ & $\mathrm{~N}=22$ & $\mathrm{~N}=62$ & $\mathrm{~N}=59$ & $\mathrm{~N}=24$ \\
laws & $35.9 \%$ & $8.4 \%$ & $23.7 \%$ & $22.5 \%$ & $9.16 \%$ \\
\hline Knowledge of Harassment laws & $\mathrm{N}=378$ & $\mathrm{~N}=116$ & $\mathrm{~N}=270$ & $\mathrm{~N}=184$ & $\mathrm{~N}=99$ \\
& $35.32 \%$ & $10.84 \%$ & $25.23 \%$ & $17.19 \%$ & $9.25 \%$ \\
\hline
\end{tabular}

Graph: 6

Analysis of research question no six (knowledge of harassment laws) 


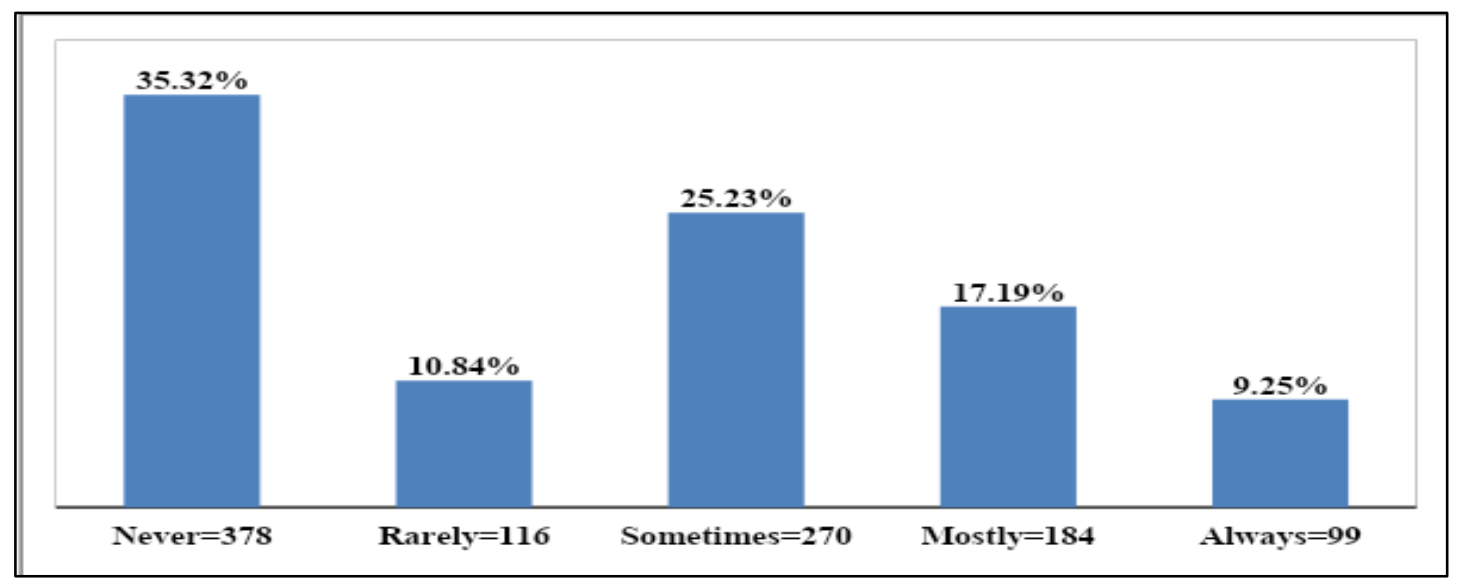

According to the above table and graph, the overall analysis of the items of the research question number six showed that $35.32 \%$ responded never, $23.41 \%$ responded rarely, $25.23 \%$ responded sometimes, $17.19 \%$ respondedmostly, $9.25 \%$ responded alwaysknew about the safeguards provided by the laws against the workplace harassment during the service period.

\section{Analysis of Research Question No. Seven (Head's Steps for prevention Harassment)}

Research question No Seven was about necessary steps that taken by heads tosupport the victim to prevent the harassment. For the answer of this Research Question, four items were developed. The items were from Seventy one to seventy four whereas their analysis is as under.

Table: 7

Analysis of research question no seven (head's steps for prevention harassment)

\begin{tabular}{|l|l|l|l|l|l|}
\hline Statement No and Theme & Never & Rarely & $\begin{array}{l}\text { Some } \\
\text { times }\end{array}$ & Mostly & Always \\
\hline $\begin{array}{l}\text { 71.Low ratio of women cause } \\
\text { harassment }\end{array}$ & $\begin{array}{l}\mathrm{N}=54 \\
20.6 \%\end{array}$ & $\begin{array}{l}\mathrm{N}=26 \\
9.92 \%\end{array}$ & $\begin{array}{l}\mathrm{N}=78 \\
29.8 \%\end{array}$ & $\begin{array}{l}\mathrm{N}=69 \\
26.3 \%\end{array}$ & $\mathrm{~N}=35$ \\
\hline $\begin{array}{l}\text { 72.Un-Enforcement of laws cause } \\
\text { harassment }\end{array}$ & $\mathrm{N}=53$ & $\mathrm{~N}=23$ & $\mathrm{~N}=83$ & $\mathrm{~N}=60$ & $\mathrm{~N}=43$ \\
\hline $\begin{array}{l}\text { 73.Head's response harassment } \\
\text { complain }\end{array}$ & $20.2 \%$ & $8.78 \%$ & $31.7 \%$ & $22.9 \%$ & 16.45 \\
\hline $\begin{array}{l}\text { 74.Head makes accountable } \\
\text { harasser }\end{array}$ & $\mathrm{N}=66$ & $\mathrm{~N}=15$ & $\mathrm{~N}=83$ & $\mathrm{~N}=56$ & $\mathrm{~N}=42$ \\
\hline & $25.2 \%$ & $5.73 \%$ & $31.7 \%$ & $21.4 \%$ & $16 \%$ \\
\hline
\end{tabular}




\begin{tabular}{|lll|l|l|l|l|l|}
\hline $\begin{array}{l}\text { Head's steps } \\
\text { harassment }\end{array}$ & for & prevention & $\mathrm{N}=243$ & $\mathrm{~N}=82$ & $\mathrm{~N}=302$ & $\mathrm{~N}=244$ & $\mathrm{~N}=177$ \\
& & $23.18 \%$ & $7.82 \%$ & $28.81 \%$ & $23.28 \%$ & $16.88 \%$ \\
\hline
\end{tabular}

\section{Graph: 7}

\section{Analysis of research question no seven (head's steps for prevention harassment)}

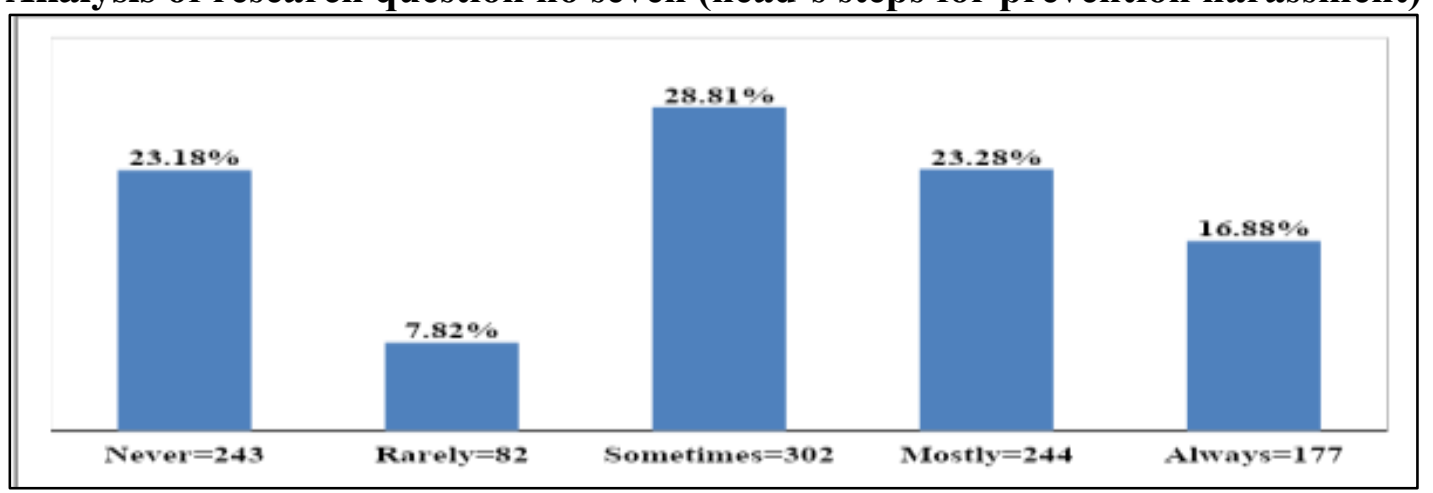

According to the above table and graph, the overall analysis of the items of the research question number seven revealed that $23.18 \%$ responded never, $7.82 \%$ responded rarely, $28.81 \%$ responded sometimes, $23.28 \%$ responded mostly, $16.88 \%$ responded always regarding the low ratio of working women and the law is not enforced whereas the head strictly responded on the complaint and made accountable one who was charged on the account workplace harassment during the service period in the working hours in the educational institutions.

\section{Consolidated Analysis of Experiences of Working Women}

Table: 8

Consolidated Experiences of working women regarding Harassment

\begin{tabular}{|l|l|c|c|c|c|c|c|}
\hline RQ-No & $\begin{array}{l}\text { Main Theme/ } \\
\text { Harassment }\end{array}$ & $\begin{array}{l}\text { No of } \\
\text { Items }\end{array}$ & Never & Rarely & $\begin{array}{c}\text { Some } \\
\text { times }\end{array}$ & Mostly & Always \\
\hline $\mathbf{1}$ & Verbal Harassment & & $\mathrm{N}=969$ & $\mathrm{~N}=496$ & $\mathrm{~N}=838$ & $\mathrm{~N}=244$ & $\mathrm{~N}=70$ \\
& & 10 & $37.02 \%$ & $18.95 \%$ & $32.02 \%$ & $9.32 \%$ & $2.67 \%$ \\
\hline $\mathbf{2}$ & Physical Harassment & & $\mathrm{N}=2552$ & $\mathrm{~N}=1075$ & $\mathrm{~N}=1334$ & $\mathrm{~N}=227$ & $\mathrm{~N}=52$ \\
& & 20 & $48.70 \%$ & $20.51 \%$ & $25.45 \%$ & $4.33 \%$ & $0.99 \%$ \\
\hline $\mathbf{3}$ & Religious \& & & $\mathrm{N}=2106$ & $\mathrm{~N}=805$ & $\mathrm{~N}=776$ & $\mathrm{~N}=98$ & $\mathrm{~N}=42$ \\
& psychological Harassment & 14 & $53.06 \%$ & $21.95 \%$ & $20.66 \%$ & $2.67 \%$ & $1.14 \%$ \\
\hline $\mathbf{4}$ & Cyber Harassment & & $\mathrm{N}=1946$ & $\mathrm{~N}=856$ & $\mathrm{~N}=444$ & $\mathrm{~N}=80$ & $\mathrm{~N}=76$ \\
& & 14 & $60.30 \%$ & $23.33 \%$ & $12.10 \%$ & $2.18 \%$ & $2.07 \%$ \\
\hline $\mathbf{5}$ & Immoral Harassment & 8 & $\mathrm{~N}=1305$ & $\mathrm{~N}=444$ & $\mathrm{~N}=282$ & $\mathrm{~N}=54$ & $\mathrm{~N}=11$ \\
& & & $68.82 \%$ & $23.41 \%$ & $14.87 \%$ & $2.84 \%$ & $0.58 \%$ \\
\hline $\mathbf{6}$ & Knowledge of & & $\mathrm{N}=378$ & $\mathrm{~N}=116$ & $\mathrm{~N}=270$ & $\mathrm{~N}=184$ & $\mathrm{~N}=99$ \\
& Harassment Laws & 4 & $35.32 \%$ & $10.84 \%$ & $25.23 \%$ & $17.19 \%$ & $9.25 \%$ \\
\hline $\mathbf{7}$ & Head's Steps for & & $\mathrm{N}=243$ & $\mathrm{~N}=82$ & $\mathrm{~N}=302$ & $\mathrm{~N}=244$ & $\mathrm{~N}=177$ \\
& Prevention of Harassment & 4 & $23.18 \%$ & $7.82 \%$ & $28.81 \%$ & $23.28 \%$ & $16.88 \%$ \\
\hline
\end{tabular}




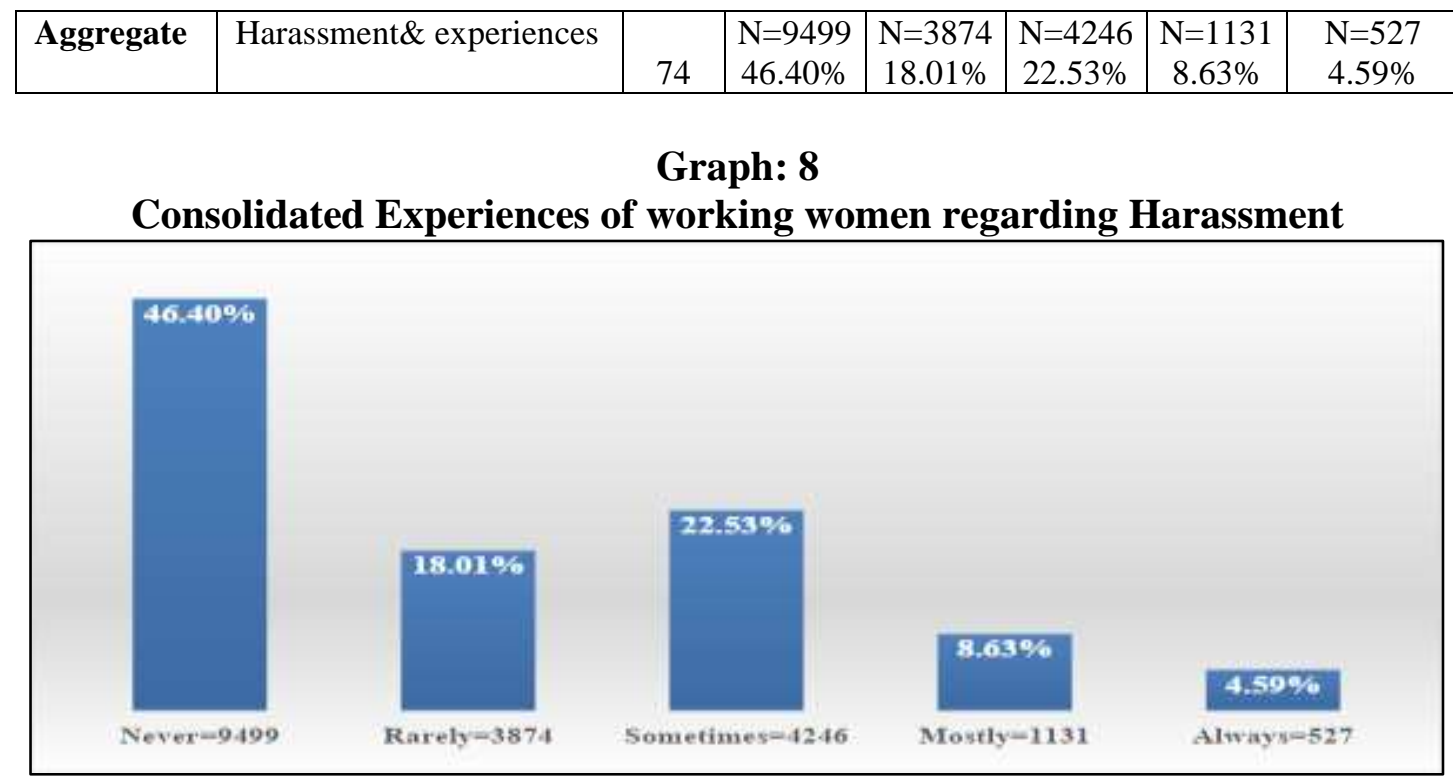

From the above table\& graph $37.02 \%$ replied never, $18.95 \%$ responded rarely, $32.02 \%$ responded sometimes, $9.32 \%$ responded mostly,2.67\% responded always regarding experienced verbal harassment during the service period in the public schools while $48.70 \%$ never, $20.51 \%$ responded rarely, $25.45 \%$ responded sometimes, $4.33 \%$ responded mostly, $0.99 \%$ responded always regarding experienced physical harassment during the service period in the Schools, while 53.06\% never, $21.95 \%$ responded rarely, $20.66 \%$ responded sometimes, $2.67 \%$ responded mostly, $1.14 \%$ responded always regarding experienced religious and psychological harassment during the service while $60.30 \%$ never, $23.33 \%$ responded rarely, $12.10 \%$ responded sometimes, $2.18 \%$ responded mostly, $2.07 \%$ responded always regarding experienced cyber harassment, as $68.82 \%$ never, $23.41 \%$ responded rarely, $14.87 \%$ responded sometimes, $2.84 \%$ responded mostly, $0.58 \%$ responded always regarding experienced immoral harassment during the service period in the working hours in the Schools. The overall analysis showed that $35.32 \%$ never, $23.41 \%$ responded rarely, $25.23 \%$ responded sometimes, $17.19 \%$ responded mostly, $9.25 \%$ responded always knew about the safeguards provided by the laws against the workplace harassment during the working hours in the educational institutions. The above table and graph the data showed $23.18 \%$ never, $7.82 \%$ responded rarely, $28.81 \%$ responded sometimes, $23.28 \%$ responded mostly, $16.88 \%$ responded always the low ratio of working women and the law is not enforced whereas the head strictly responded on the complaint and made accountable one who was charged on the account workplace harassment during the service period in the working hours in the educational institutions. According to the overall responses regarding all types of harassment $46.40 \%$ responded never, $18.01 \%$ responded rarely, $22.53 \%$ responded sometimes, $8.63 \%$ responded mostly whereas $4.59 \%$ responded always regarding harassment \& knowledge regarding 
safeguards provided by the law and employers' steps for the prevention of harassment in the selected public schools.

\section{Conclusions}

Pakistan is a country where the population of women is about $49 \%$ and men $51 \%$ according to the census population of Pakistan (PBS, 2017). Whereas only $23 \%$ are in all government jobs as compare to $77 \%$ of man (World-Bank-Indicators, 2017). Working women have been facing a number of challenges in all aspects in which harassment is heinous and terrible in all over the world including Pakistan. This study explored the experiences of working women regarding harassment in the public Schools. It has been concluded that harassment existed in the educational institutions. It was revealed that a number of working women from public schools were harassed verbally, physically, religiously, racially, sexually and psychologically by their heads and colleagues a number of working women of public schools were targeted by cyber harassment means through internet application, on the basis of religion, sect, caste, race, sex, age, voice, body figure, height and disability. study analyzed that the verbal harassment usually caused by personality conflicts working women were harassed by needless shouting or noise, rude or vulgar attitude, humiliating and degrading behavior, joking and mockery, while attacking physically, bullying, assaulting, threatening, shoving, hitting, kicking and shoving, shaking fists angrily, destroying property to frighten, slapping and pushing, targeted on the basis of on the basis of religion, sect, caste, race, sex, age, voice, body figure, height and disability, they were also harassed by frequently and repeatedly insulting, rude and abusive language, ruthless and harsh language, shoving, pulling, bullying, grabbing, giving unfeasible targets, tiny period that means discriminatory, religion and psychological harassment existed to some extent . women harassed by sharing text, comment, immoral photos, videos, messages, calls and emails by the help of the internet applications like face book, twitter, what's app and Skype that is counted in cyber harassment. Working women provoked by asking and sharing undesirable immoral photos, posters, comments, jokes, questions or touching and gestures. It was found that they were proposed for somewhat of worth for an immoral favor that alarms the seriousness of immoral harassment. It was concluded that the working women know about the harassment laws their perception was that the law provides safeguard against workplace harassment. Majority $46.40 \%$ responded never regarding harassment during the service period in the public schools of SBA district while $8.63 \%$ responded mostly whereas $4.59 \%$ responded always, its mean this study explored (either very low reported) harassment in workplaces.

\section{Recommendations}


Laws should be legislated or amended the existed laws regarding verbal, physical, religious, psychological harassment in order to prevent verbal harassment.

CCTV cameras should be used to monitor the activities of the head and colleagues in the educational institutions.

Stakeholders should take steps to eradicate physical harassment from the educational instaurations.

The heads should not allow any discussion regarding religion or discrimination in the institutions.

Cyber laws should more effective and easier to access for a common rural area working women.

The ratio of working women should be increased in educational institutions.

A media campaign should be started in order to educate the working women regarding harassment.

Proper orientation and implementation of law regarding women harassment at workplaces

Anti-harassment committees should be constituted that should visit educational instaurations in order to study the situations and to be taken necessary steps in order to prevent harassment.

The mechanism process of dealing/reporting regarding harassment by working women should be more effective in educational institutions.

\section{Limitation of Study}

The study was limited to the experiences \&opinion of selected working women of public schools of SBA district who are performing their administrative \&academic responsibilities.

\section{References}

Agarwal, B. \& Bina, A. (1994). A Field of One's Own: Gender and Land Rights in South Asia (Vol. 58). Cambridge University Press.

Agervold. (2007). Bullying at Work: A Discussion of Definitions and Prevalence, Based on an Empirical Study. Scandinavian Journal of Psychology, vol.48:2, pp.161172.

Ashforth, B. (1994). Petty Tyranny in Organizations. Human Relations, vol.47:7, pp.755-778. 
Adeel, M. \& Yeh, A. G. (2018). Gendered Immobility: Influence of Social Roles and Local Context on Mobility Decisions in Pakistan. Transportation Planning and Technology, vol.41:6, pp.660-678.

Beehr, \& Bowling. (2006). Workplace Harassment from the Victim's Perspective: A Theoretical Model and Meta-Analysis. Journal of Applied Psychology, vol.91:5, p.998.

Bame, R. M. (2013). A Historical Study on Workplace Bullying (Doctoral dissertation, University of Phoenix) UMI dissertation publishing, ProQuest LLC p.97-101

Brodsky. (1976). Workplace Harassment and Bullying of Working Women. Book Mobbing and victimization/, vol.6:2, p.186.

Boso, L. A. (2012). Urban bias, rural sexual minorities, and the courts. Dukeminier Awards: Best Sexual Orientation and Gender Identity Law Review, 13, i.

Blase, J. \& Blase, R. R. (2003). Breaking the silence: Overcoming the problem of principal mistreatment of teachers. Corwin Press.

Collins-Dictionary.(2019). Harassment Definition Retrieved on 05 May 2018/ Retrieved from https://www.collinsdictionary.com/dictionary/english/harassment.

Einarsen, S., Hoel, H., Zapf, D. \& Cooper, C. L. (2011). The Concept of Bullying and Harassment at Work: The European Tradition. Bullying and Harassment in the Workplace. Developments in Theory, Research and Practice, vol.2, pp.3-40.

Davenport. (2014). Educators' Perspectives on Having Been Cyber Harassed (Doctoral Dissertation) Liberty University, Lynchburg, VA p.33-34.

Frawley. (2007). Perversion of Power: Sexual Abuse in the Catholic Church. Nashville Vanderbilt University Press.p.206-211

Fox, J., \& Tang, W. Y. (2017). Women's Experiences with General and Sexual Harassment in Online Video Games: Rumination, Organizational Responsiveness, Withdrawal and Coping Strategies. New Media \& Society, vol.19:8, pp.1290-1307.

Gruber, J. E. \& Fineran, S. (2008). Comparing the Impact of Bullying and Sexual Harassment Victimization on the Mental and Physical Health of Adolescents. Sex Roles, vol.59:1-2, p.1. 
Gallup. (2017). Daily pool on street harassment/ nationwide public opinion pool /published on 2nd january 2018/Retrieved on 13Saptember 2018, Retrieved from http://gallup.com.pk/wp-content/uploads/2018/01/Public-Opinion-Polling-onSexual-Harassment-1.pdf

Hamdan. (2005). Women and Education in Saudi Arabia: Challenges and Achievements. International Education Journal, vol.6:1, pp.42-64.

Hangartner. (2015). The Association between Sexual Harassment and Suicidality Among College Women. (Graduate Theses and Dissertations) Published by USF scholar commonsp. no. 01-12

Khan. (2011). Zina, Transnational Feminism and the Moral Regulation of Pakistani Women. UBC Press; 2011 Nov 1. Social Sciences p.108.

Law, D. T. (2011). Psychosocial Safety Climate as a Lead Indicator of Workplace Bullying and Harassment, Job Resources, Psychological Health and Employee Engagement. Accident Analysis \& Prevention, vol.43:5, pp.1782-17.

Leymann. (1990). Mobbing and Psychological Terror at Workplaces. Violence and Victims, vol.5:2, pp.119-126.

Merriam-Webster. (2018). Harassment Retrieved 19August 2018. Retrieved fromhttps://www.merriam-webster.com/dictionary/sexual\%20harassment.

McCarthy, K. A. (2014). e-Rudeness at Work: The Impact of Rude Email on Employee Performance (Doctoral dissertation, UC Irvine). p.111-115

Ong, A. (2006). Neoliberalism as exception: Mutations in citizenship and sovereignty. Duke University Press. pp.09-13.

PBS. (2017). "Chief Statistician/Chief Census Commissioner, PBS | Pakistan Bureau of Statistics".Population census/ Chief Statistician, Govt. of Pakistan. Retrieved 16 March 2017. Retrieved from www.pbs.gov.pk.

Rayner, C. \& Keashly, L. (2005). Bullying at Work: A Perspective from Britain and North America. In S. Fox \& P. E. Spector (Eds.), Counterproductive work behavior: Investigations of Actors and Targets (p. 271-296). American Psychological.

Rigby, K. (2007). Bullying in Schools: And What to do About It. Aust Council for Ed Research. ACER Press 2007. p.109-115 
RSU. (2014-15). Education and Literacy Department Government of Sindh / Reform Support Unit/ District profile SBA. Retrieved 15 Jan 2018 Retrieved fromhttp://www.rsu-sindh.gov.pk/contents/SEMIS/SEP2014-15/SBA\%20District \%20Profile\%202014-15\%20Final.pdf

Spigel, L. \& McRobbie, A. (2007). Interrogating Post Feminism: Gender and the Politics of Popular Culture. Duke University Press.

True, J. (2012). The Violence against Women. Oxford University Press. Book Published 2012/ Chapter One p.no.03-17.

The-Dawn. (2017). Harassment in Pakistan/ Special report on sexual Harassment at Workplace in Pakistan. Retrieved on 20 May 2018 from https://www.dawn.com/news/1395215

UN. (2015). Global Women Harassment Index. Retrieved on 10 June 2019, from https://unstats.un.org/unsd/gender/downloads/WorldsWomen2015_report.pdf

WPA. (2010). Women protection Act/ The Protection against Harassment of Women at the Workplace Act 2010/ Retrieved on 20 May 2018, from https://sindh.gov.pk/dpt/PROVINCIAL-OMBUDSMAN/Act2010.pdf

Willard. (2007). Cyber Bullying and Cyber Threats: Responding to the Challenge of Online Social Aggression, Threats and Distress. Published 2007/311p Research Press.p.no 10-15

World-Bank-Indicators. (2017). World Bank Indicators about the Women in Jobs. Retrieved on 27 May 2018, from https://books.google.com.pk/books?id=eG6gAwAAQBAJ\& printse $=$ frontcover $\& d q=$ World-Bank-Indicators. $+(2017) .+$ world + bank + indicators + about + the + women + in + jobs + . \& hl $=e n \& s a=X \& v e d=2 a h U K E w i D 7-K D 6-$ HqAhVESxUIHUpxAP8Q6AEwAHoECAAQAg\#v=onepage \& $q \& f=$ false

Mureed Hussain Laghari is a Research Associate in the Department of Education, Shaheed Benazir Bhutto University, Shaheed Benazirabad, Pakistan.

Prof. Dr. Tayyaba Zarif is Dean, Faculty of Social Science, Shaheed Benazir Bhutto University, Shaheed Benazirabad, Pakistan. 
Dr. Safia Urooj is Incharge and an Assistant Professor in the Department of Teacher Education, University of Karachi, Karachi, Pakistan. 